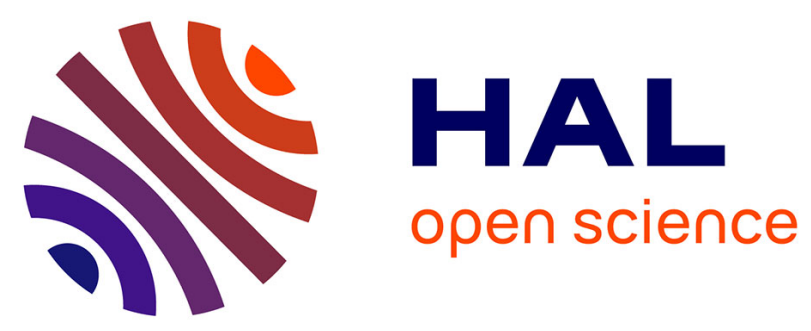

\title{
Restoration of Degraded Lands Affected by Salinization Process Under Climate Change Conditions: Impacts on Food Security in the Senegal River Valley
}

\author{
Mateugue Diack, Tegaye Diop, Ramatoulaye Ndiaye
}

\section{- To cite this version:}

Mateugue Diack, Tegaye Diop, Ramatoulaye Ndiaye. Restoration of Degraded Lands Affected by Salinization Process Under Climate Change Conditions: Impacts on Food Security in the Senegal River Valley. Rattan Lal; Bal Ram Singh; Dismas L. Mwaseba; David Kraybill; David O. Hansen; Lars Olav Eik. Sustainable Intensification to Advance Food Security and Enhance Climate Resilience in Africa, Springer, pp.275-288, 2014, 978-3-319-09359-8. 10.1007/978-3-319-09360-4_14 . hal-02270206

\section{HAL Id: hal-02270206 \\ https://hal.science/hal-02270206}

Submitted on 4 Sep 2019

HAL is a multi-disciplinary open access archive for the deposit and dissemination of scientific research documents, whether they are published or not. The documents may come from teaching and research institutions in France or abroad, or from public or private research centers.
L'archive ouverte pluridisciplinaire HAL, est destinée au dépôt et à la diffusion de documents scientifiques de niveau recherche, publiés ou non, émanant des établissements d'enseignement et de recherche français ou étrangers, des laboratoires publics ou privés. 


\title{
Restoration of Degraded Lands Affected by Salinization Process under Climate Change Conditions: Impacts on Food Security in the Senegal River Valley
}

\author{
Mateugue Diack ${ }^{1}$, Tegaye Diop ${ }^{2}$, and Ramatoulaye Ndiaye ${ }^{3}$ \\ ${ }^{1}$ UFR des Sciences Agronomiques, d'Aquaculture et de Technologies Alimentaires, \\ Universite' Gaston Berger, Saint-Louis, Senegal \\ ${ }^{2}$ UFR des Sciences Economiques et de Gestion, Universite' Gaston Berger, Saint-Louis, Senegal \\ ${ }^{3}$ Agricultural Research Institute of Senegal, Saint-Louis, Senegal
}

\begin{abstract}
With the progressive degradation of agricultural lands due to climate change, there is a need to document how land responds to management practices and their resilience to salinization processes. Salinization is a problem associated with agriculture and it constitutes a constraint which results in inappropriate practices. In addition, agriculture intensification and changes in temperature and precipitation patterns expected from climate change are likely to affect the salt- water balance of fragile ecosystems. Information on the relationship between climate change and salt-affected land salinization processes is scattered. Little has been done to highlight the most affected or vulnerable areas or to promote practices that can be used to adapt agricultural production in fragile areas to climate change. This study will contribute to food security and reducing the stress on ecosystems. This study relates land management practices to lands degraded and salinized due to climate change. Several land management practices have been used to evaluate the level of restoration of degraded lands. Changes in temperature, relative humidity, evapora- tion, solar radiation, and soil temperature combined with agricultural management practices driven by different cropping systems were used to evaluate the best and most adapted management practices for degraded lands that are dedicated to agriculture. Results suggest that regular seasonal cropping under irrigation might be recommended for degraded lands to assure sustainable food security.
\end{abstract}

Keywords: Climate change, Agriculture, Degraded land, Salinization, Food security 


\section{Introduction}

Land degradation due to salinization has revealed negative interactions that have been developing for decades from an increase in population and a decrease of crop production in developing countries. This has aggravated inequalities in food production across regions (Parry et al. 2005). Moreover, food insecurity is likely to increase with climate change unless early warning systems and development programs are used more effectively (Brown and Funk 2008).

Developing countries in sub-Saharan Africa are more vulnerable because of the dominance of agriculture in their economies, the scarcity of capital for adaptation measures, warmer baseline climates, and heightened exposure to extreme events (Tubiello and Fischer 2007, 2013; Brown and Funk 2008). Soils affected by salinization processes have become a major environmental issue. Nearly 800 million hectares of land worldwide, more than $6 \%$ of the total surface area of lands, are affected by salinization processes. In addition, climate changes aggravate losses of arable lands in the arid and semi-arid zones (Boivin and Le Brusq 1985). In Senegal, estimated total lands affected by salinization processes are 1,000,000 ha to $1,700,000$ ha (Gobin et al. 2003; Sadio 1991). More recent studies conducted by the National Institute of Pedology in Senegal (2008) have estimated the total land affected by salinization processes at 996,950 ha (Fig.1). The same studies underlined that the level of salinization requires setting up strategy control the phenomenon and determining the origin or the source of the salt within the considered soil. Those studies did not identify the arable surface area affected by

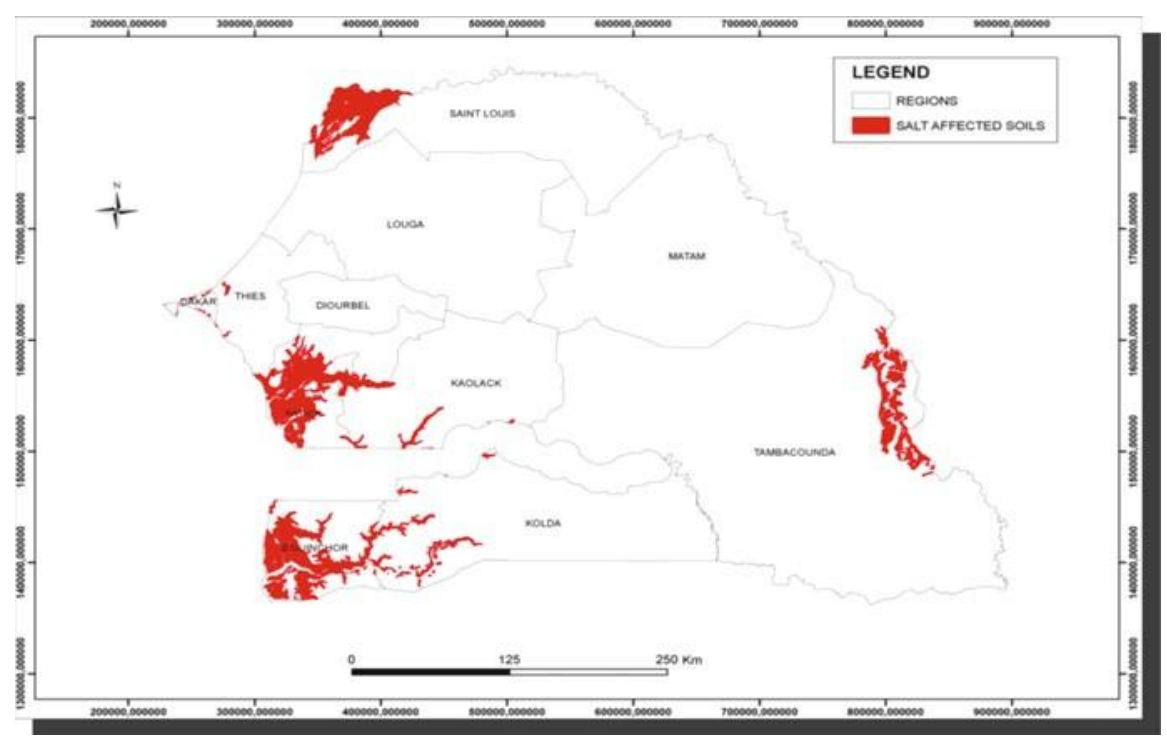

Fig.1 Distribution of the affected zones by salinization processes (Source: National Institute of Pedology 2008) 


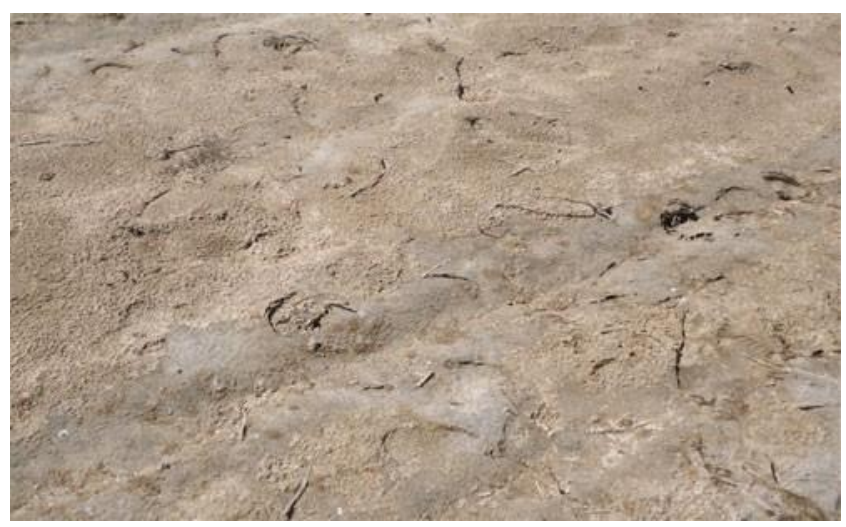

Photo.1 Soil degradation due to salinization process (T. Diop)

The salinization process or indicate the sources of specific salinization processes for any surface area listed.

Salinization processes are near to irreversible in the case of heavy-textured soils with high levels of swelling clay (Marius 1995; Sadio 1986). The nature of the salt, the plant species, and even the individuality of the plant (e.g., structure and depth of the root system) determine the concentration of soil-salt levels at which a crop or plants will succumb (Photo.1). Consequently, there has been a progres- sive reduction of crop production regardless of whether it is for industrial or feeding purposes (Diop 2013). Therefore, improving and maintaining croplands to improve crop productivity are critical when techniques are adapted to restore lands affected by salinization processes (Marius 1985). Although a combination of efficient drainage and flushing of the soil by water is often used, the leaching of salts from the profile is rarely effective (Boivin et al. 1995, 1998). Because the reclamation, improvement, and management of salt affected soils necessitate complex and expensive technologies, all efforts must be taken for the efficient prevention of these harmful processes (Lal 2000).

Adequate soil and water conservation practices based on a comprehensive soil or land degradation assessment can become an early warning system that provides possibilities for efficient salinity (or alkalinity) control, the prevention of these environmental stresses, and their undesirable ecological, economic, and social consequences (Le Brusq and Loyer 1983). As adaptation practices refer to actual adjustments or changes in decision environments, which might ultimately enhance resilience or reduce vulnerability to observed or expected changes in climate, a changing climate will result in considerable changes in natural vegetation and in land use practices (Adger et al. 2007). These changes in turn result in a feedback effect on the climate, which considerably affects the field water cycle and soil formation/degradation processes (Lal and Stewart 1994; Lal et al. 1989; Várallyay 2007; Harnos and Csete 2008; Várallyay and Farkas 2008). The integral influence of climate, hydrology, and vegetation land use changes are reflected by the fiel 
water balance and soil moisture regimen (Várallyay 1990, 1994, 2009; Farkas et al. 2008). Climate change and its hydrological consequences may result in the significant modification of soil conditions (Várallyay 2010). Changes in temperature, precipitation, natural vegetation, and land use practices will result in significant changes in crop production. In addition, climatic changes exacerbate the loss of woody lands in the arid and semi-arid regions (Zeng 2003). Soil salinity is also a serious problem in areas where the groundwater of high salt content is used for irrigation. The most serious salinity problems are faced by the irrigated arid and semi-arid regions of the world, and it is in these very dry regions that irrigation is essential to increase agricultural production to satisfy food requirements. The problem of soil degradation is a serious threat to the welfare of mankind. Although degradation of the land has always characterized man's systematic use of it, the process has accelerated in recent decades, precisely at a time when population growth and rising expectations have begun to demand enormous increases in food production. The issue is of overwhelming urgency. As the soil is subject to degradation, the cost of reclaiming it becomes higher, rising sharply until the threshold beyond which reclamation is no longer economically feasible is passed. Nearly $50 \%$ of the irrigated land in the arid and semi-arid regions has some soil salinization problems. It is generally agreed that the future food needs of the increasing population will be met by directing the efforts of all concerned stakeholders (Le Gal 2001). D'aquino-Passouant (1995) studied the salinization process of the soils and noticed essentially two issues: the drainage of water and the rising of salt by capillarity. He revealed that the first process depended mostly on the nature and type of soil, as percolation of the vertisols and alfisols varied from 1 to 3 $\mathrm{mm}$ /day. Rising water by capillarity was due to the presence of shallow and high in salt groundwater that probably occurred during different periods of sea transgressions and regressions 2,000 years (before JC). This left a high quantity of soluble salt that remained at the fossil state in the soil of the delta, which explains the origin of the saline groundwater (Ceuppens and Wopereis 1999). Cropping systems are also responsible for rapid degradation of the soils of the delta as well as most of the abandoned private farms (Breman and Sissoko 1994; Dunia 1995). Loyer (1989) underlined that a converted system for irrigation without drainage and rice cultivation under permanent flooded conditions helps the desalinization process first for the soils and then for the groundwater. This induced and unexpected alkalinization of these soils due to a rise in the groundwater in which movements are not well controlled. This raises the issue of evacuating drainage water. Sadio (1991) described a similar process with the tanns of Sine Saloum, which are characterized by a remarkable heterogeneity due to their morphology and physical and chemical properties. Their characteristics are closely related to topography, type of material, and hydrology (Sy 2008). Since 1971, their pedogenetic evolution has led to a severe drought all over the country, particularly in the fluviomarin fields (Michel 1973). This has led to dramatic consequences for the social and ecological environment (Enda 1986). Moreover, insufficient rainfall induced by the aridness of the climate has triggered and amplified salt concentration and acidification of the soils all over the area. This salt concentration, which was spread out a little bit few decades ago, has quickly reached all soils, from the terrace up to the linked 


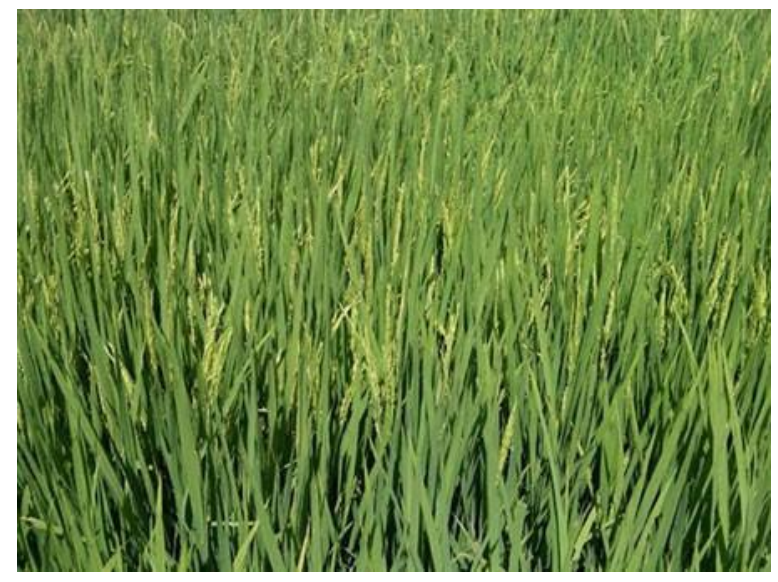

Photo. 2 a rice field under optimal management practices

Colluviums. Data collected from the surveys conducted in several villages along the arm of the river showed that according to farmers, rice cultivation was the best management practice for restoring degraded salt affected lands because of its rooting system, its capacity to grow under flooded conditions, and its ability to be a salt tolerant crop (Photo.2).

However, irrigation is often costly and technically complex, and it requires skilled management. Failure to apply efficient principles of water management may result in the wastage of water through seepage; over-watering and inadequate drainage create waterlogging and salinity problems that reduce the soil productivity, eventually leading to loss of cultivable land. The problems of salt-affected soils are old, but their magnitude and their intensity have been increasing fast due to large-scale efforts to irrigate additional areas in recent decades. The problems have been made worse by scaling up the irrigation systems without adequate provision for drainage, and they are being aggravated by poor water management practices and unsound reclamation procedures. The general characteristics and basic principles involved in the identification, reclamation, and management of salt-affected soils are the same throughout the world. In the delta of the Senegal River where the study took place, the salinity of the soils is a real issue with an anthropic origin. This issue touches the low and middle delta of the River Valley. The objective of this study was to (1) analyze the dynamics of salinization process as related to climate change and (2) compare different management practices to remediate saline soils for rice cropping.

\section{Materials and Methods}

The site was located in the upper limit of the delta of the Senegal River Valley. Over 900 ha of land with different soil orders identified as Inceptisol (18\%), Vertisol (36\%), Alfisol (14\%), and Aridisol (30\%) were severely affected by the 
salinization process (Soil Survey Staff 1992). To restore the degraded soils, different management practices were compared to determine the most efficient one that can be readily adopted by farmers. They consisted of (1) abandoning lands with no watering and no cropping (T1); (2) leaching followed by rice cropping (T2); (3) leaching followed by continuous rice cropping (T3); (4) leaching followed by crop rotation with rice, sugarcane, and fallow (T4); and (5) leaching followed by continuous rice cropping over years (T5). The leaching process consisted of watering the plots with an amount of water that dissolved the accumulated salts in the soil to make them move downward to the root zone or shallowly wash the soil from the salt. The leaching process was the same as for all management practices except for the "abandoned plot." Plots receiving leaching treatments were arranged in bands of 0.7 ha separated by small flood banks. The dimensions of the bands differed from one plot to another. This way of turning plots into smaller bands ensured good coverage of the soil with a film of water and thus established the correct homogeneity of the plot. The watering by band consisted of having each band receive water up to a $40 \mathrm{~cm}$ height. In general, the frequency of watering was once every 25-30 days. After watering twice, the plot was dried out for 10 days before soil sampling at $0-20$ and $20-30 \mathrm{~cm}$ for analysis in the laboratory. Once the soil sampling was done and the experimental design was set up, water was added to the plots. Each band was watered up to a $40 \mathrm{~cm}$ height. Watering was done while controlling the level of the water table with piezometers installed in the plots. This management could not proceed without knowing the physical and chemical characteristics of the soils. The idea was then to proceed with watering in a way that had one part of the salt percolate downward to be collected by the buried drains; the other part rose up by capillarity towards the shallow zone of the soil and was drained out towards the open drains. During leaching, water was sampled regularly from the plots, the buried drains, the open drains, and from irrigation. Changes in soil salinity concentration were measured by electrical conductivity (EC) at a

1:5 soil to water ratio. Likewise, soil acidity was measured by soil $\mathrm{pH}_{\text {water }}$ at a 1:5 soil to water ratio.

\section{Results and Discussion}

In the delta of the Senegal River, salinization of the lands is one of the biggest constraints farmers are facing. This salinization process results in two phases that are characteristic of the evolution of the environment during the Nouakchotian transgression and the drought periods of the 1970-1980. During that time, marine transgression polluted the groundwater of the delta. Afterward, these waters became highly concentrated due to the fossilization of the salt. Indeed, the weakness of the flow strongly penalized traditional farming in the flooding zones as well as breeding in the falling areas. Moreover, such process favored the rising of the salty water in the bed of the river in more than hundred kilometers from the mouth 


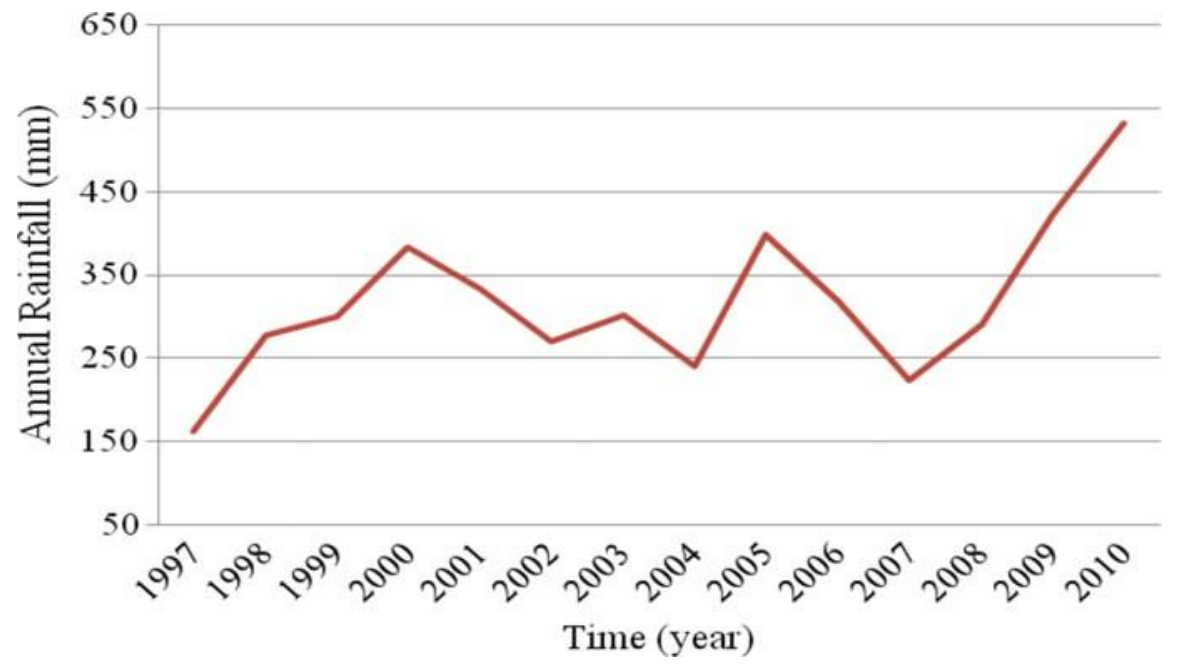

Fig. 2 Changes in mean annual rainfall over time (Source: CSS Weather Station 2011)

of the river (Guillaumie et al. 2005). This rising action led to the construction of the Diama dam in 1986 to stop the saline intrusion and develop cropping systems under irrigation. However, if water softening is a major factor in the delta, the dam is causing the reverse process in zones in the drainage basins and in certain agricultural racks where irrigation practices have no drainage systems and are not well conducted. In the delta, itinerant agriculture reduces the potential for tenure, mainly in the Boudoum zone and Lake Guiers. From a social point of view, this work will cause collective awakening of the impact of these techniques on the environment and therefore on the socio-economic activities of the populations living around the lake. Through this awakening, they should reach self-sufficiency in rice and vegetable cropping in the Dieri upland zone. The physical factors influencing the salinization processes are rainfall, temperature, relative humidity, wind speed, solar radiation, total evaporation, and population. Therefore, a monitoring process was set up and run from 1997 to 2010.

Figure 2 shows that the geographical location of the delta in the Sahelian region has two seasons with contrasting rainfall patterns in the range of 200-400 $\mathrm{mm}$. There is a short rainy season of 2-3 months and a dry season of 9-10 months. During the same period, mean annual temperatures were above $25^{\prime} \mathrm{C}$. There were extreme temperatures from $26.2^{!} \mathrm{C}$ in 1999 to $29.1^{\prime} \mathrm{C}$ in 2007 (Fig.3). An analysis of these data revealed that temperatures were higher than that usually recorded.

Maximum temperatures were above $34{ }^{!} \mathrm{C}$, and the range was significant.

During that period, temperatures ranged from 14.5 to 17 ! C.

The relative humidity was strongly influenced by the continental location and marine bangs (Ciss 2002). Analysis of the data over the last 12 years showed high 


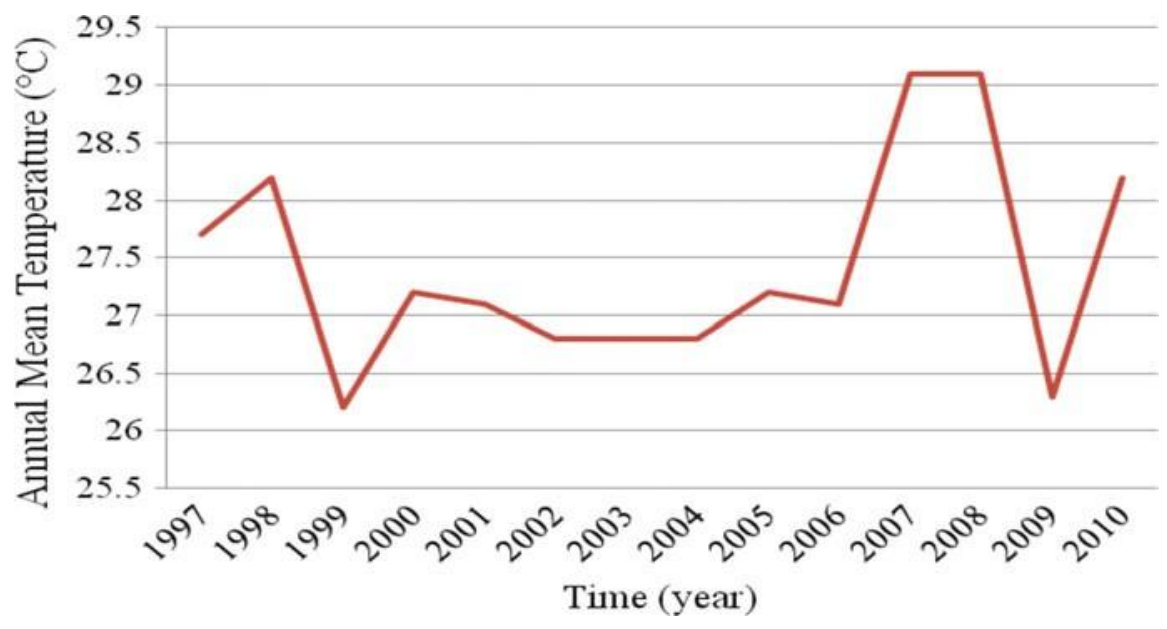

Fig. 3 Changes in annual mean temperature over time (Source: CSS Weather Station 2011)

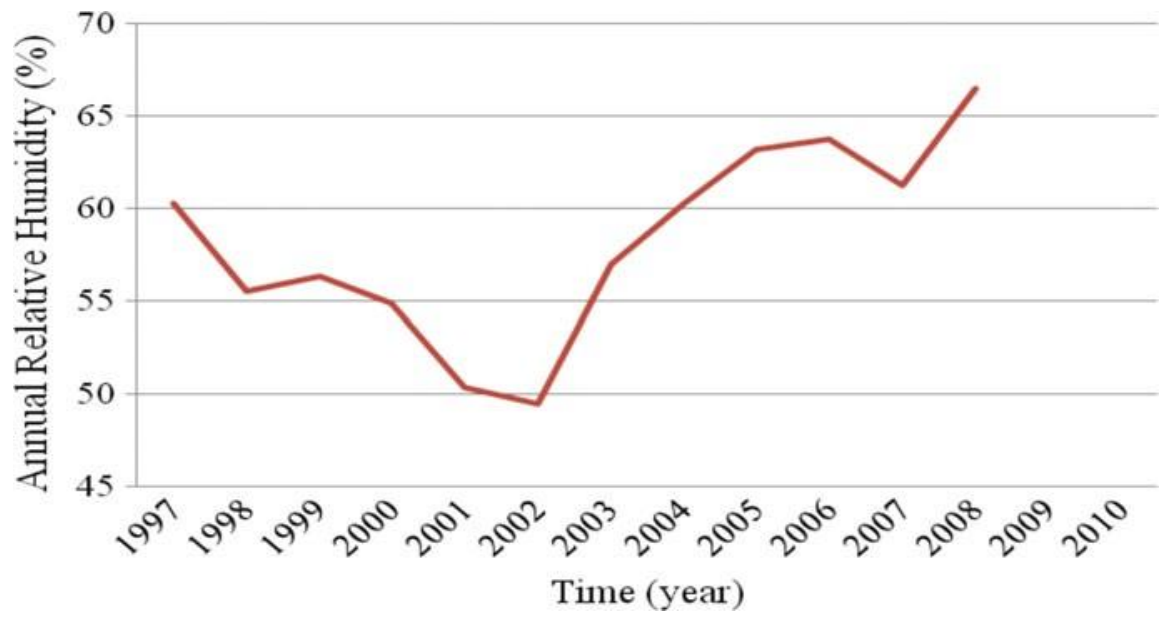

Fig.4 Changes in relative humidity, 1997-2008 (Source: CSS Weather Station 2011)

humidity, from $49.45 \%$ in 2002 to $66.54 \%$ in 2008 (Fig.4). The highest values were noted between 2004 and 2008.

Observations of all parameters seem to indicate that the period of sunshine determines evaporation. Indeed, the highest evaporation data were related to the maximum number of hours of sunshine, and this occurred during the years with high evaporation demand. This is the case for 2004 (Figs.5 and .6). With less rainfall and high temperatures over the period between 2005 and 2010, these 


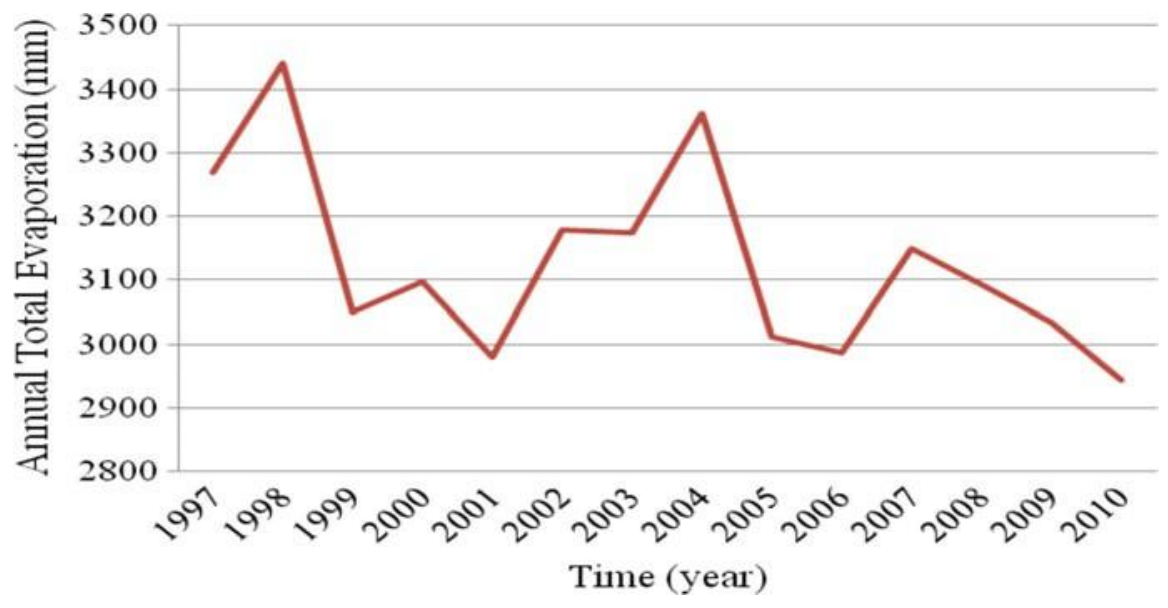

Fig. 5 Changes in total evaporation over time (Source: CSS Weather Station 2011)

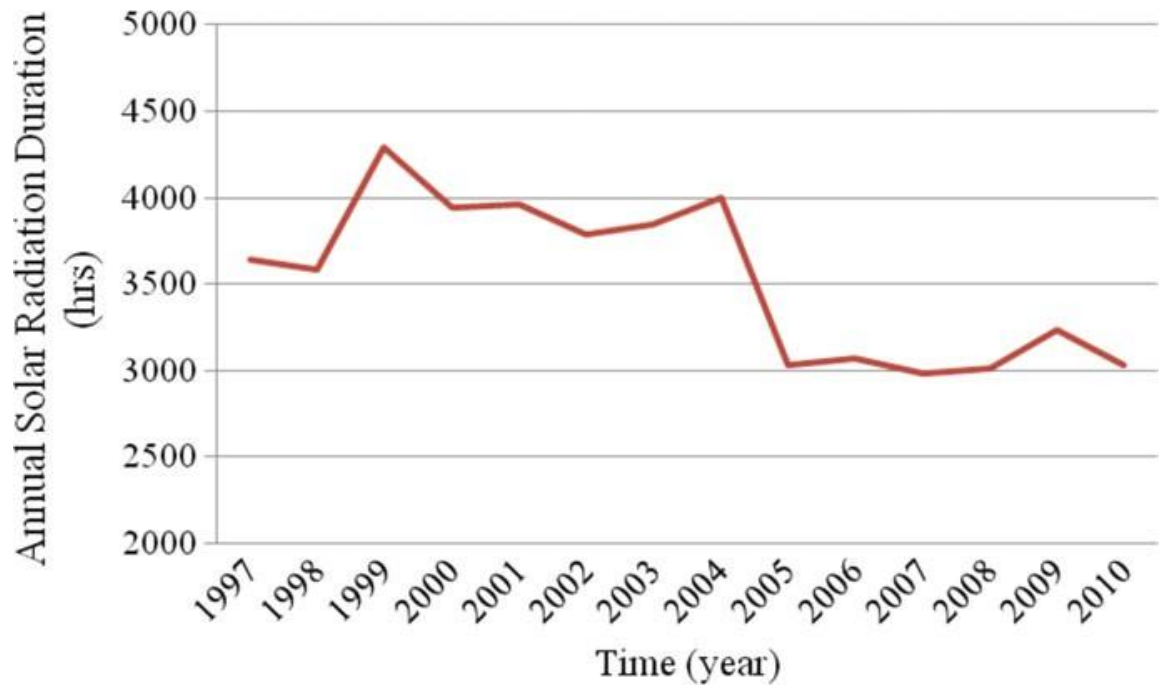

Fig.6 Changes in annual solar radiation duration over time (Source: CSS Weather Station 2011)

temperatures were almost stable (close to $35{ }^{!} \mathrm{C}$ for $\mathrm{T}_{\max }$ ), which is evidence of the climate change effect on the Sahelian zone. During this 6-year period, year 2008 recorded a shorter duration of sunshine, with $2,825 \mathrm{~h}$.

Climatic parameters and geomorphology are among other biophysical factors that influence the salinization process in the field. Aridification of the soils from in the Sahelian zone, which took place in 1960, may result from a long climate 
modification process, characterized by two big scourges in 1972-1973 and 1984-1985. Thus, changes in the sedimentary regimen in the climatic context of the Sahelian zone raised fossil salts through thermocapillarity. Such salinity levels may be favored by the shallow depth of the groundwater, which is usually in contact with the plant roots due to inadequate irrigation and a maladapted drainage system. The amount of water added to better leach a saline rooting zone depends mainly on the initial level of salinity of the soil, the soil texture, and the leaching technique used. Nevertheless, findings from the work done by Charollais and Weber (1994) did not agree with previous diagnoses. They indicated a significant decrease in the (EC) at the surface and at depths for the cultivated soil, without significant changes in exchangeable Sodium percentage (ESP). This decrease in EC is illustrated by the changes in chlorides and sodium in solutions. In conjunction with this, the level of exchangeable sodium did not change significantly, but a significant decrease of the exchangeable potassium was noticed. This decrease in EC was also observed in the delta of Senegal. Wopereis et al. (1999) confirmed that rice cultivation, whether it was drained or not, led to a desalination of the shallow layers. On irrigated rice, the presence of film water at the surface, with lower concentration, made a lateral evacuation of the salts possible along with the blocking the capillary increase in the saline in saline water and deep groundwater. In the fields alternating between cropping under dry conditions and rice cultivation, the crops grown for diversification, such as tomatoes or onions, were largely grown in irrigated fields for the villages or for private use, and most of these fields did not have a drainage system. The crops grown for diversification are mainly grown in the village's irrigated perimeters or in private perimeters, most of which do not have drainage systems. In spite of their filtering soils and unsuitability for rice cultivation-according to the extension agents and agents from development projects-farmers sometimes grow rice in these types of soils. This will allow for a leaching of the accumulated salts after few years of vegetable cropping. Before planting the crop, salt leaching was essentially done in the shallow water film and showed the effect of a flooding and evacuation cycle on changes in salinity of the surface horizon. Leaching by flooding showed that it was possible to obtain remarkable results. These results were encouraging and were obtained using a very rigorous soil and water management system for irrigation and drainage. By combining irrigation and cropping, convenient trends in the desalinization process were obtained. The set of management practices used produced different results with an overall decrease in salinity levels. The abandoned plot treatment (Fig.7) showed the highest salt content of 7.12 and $8.82 \mathrm{dS} \mathrm{cm}^{\prime \prime} 1$ at the soil surface $(0-20 \mathrm{~cm})$ and at the subsoil level $(20-30 \mathrm{~cm})$, respectively. Non-cultivated soils have a salinity level with chlorine and are totally saturated with sodium at deeper levels and are equally split into sodium, calcium, and magnesium at the surface.

The first prospection (Poitevin 1993) showed an increase in the electric conductivity (EC) in the irrigated fields in the studied zone. With the other management practices where irrigation, leaching, and cropping are combined, a gradual but significant decrease in soil salinity content was noticed (Fig.7). At the shallow 


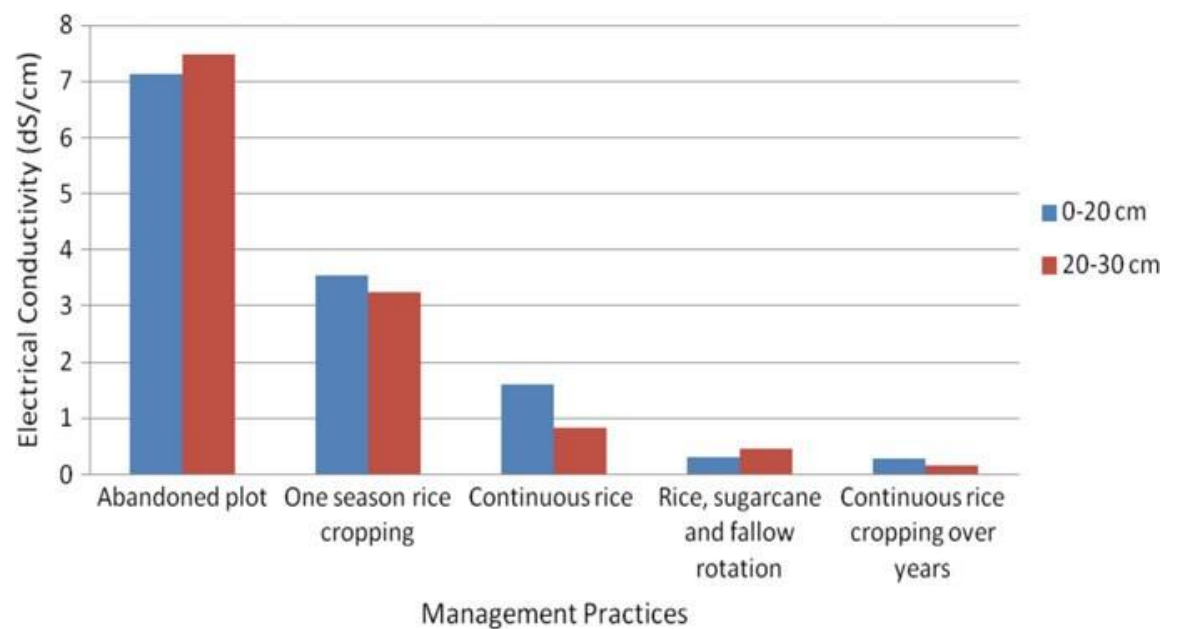

Fig.7 Changes in electrical conductivity between management practices

level $(0-20 \mathrm{~cm})$, the salinity level measured by $\mathrm{EC}_{1 / 5}$ showed a decrease from 3.54 to $0.17 \mathrm{dS} \mathrm{cm}{ }^{\prime \prime}$ in the four other management practices that went from leaching followed by rice cropping (T2) to rice cropping in the regular season (T5). The mean concentration of the salinity in the plots under leaching with different croppings varied from 0.28 to $3.54 .00 \mathrm{dS} \mathrm{cm}^{\prime 1}$ for the $0-20 \mathrm{~cm}$ horizon (Fig.7). For the $20-30 \mathrm{~cm}$ layer also, for all plots, a noticeable decrease in salt concentration was observed (3.24-0.17 dS cm "1) except for the abandoned plot (T1) where there was a saline rise through capillarity and an increase in salt concentration due to intense evaporation. At the shallow soil depth, this decrease was estimated to be $47.26 \%$ between $\mathrm{T} 1$ and $\mathrm{T} 2,45.48 \%$ between $\mathrm{T} 2$ and $\mathrm{T} 3,81.37 \%$ between $\mathrm{T} 3$ and $\mathrm{T} 4$, and $6.67 \%$ between $\mathrm{T} 4$ and T5. A comparison of these results with those from previous studies showed a noticeable decrease in the level of salinity. At a greater depth, the soil salinity decrease was estimated to be $63.27 \%$ between $\mathrm{T} 1$ and T2, $74.30 \%$ between $\mathrm{T} 2$ and $\mathrm{T} 3,44.57 \%$ between $\mathrm{T} 3$ and $\mathrm{T} 4$, and $84.78 \%$ between $\mathrm{T} 4$ and T5. The study showed that it is possible to leach soluble salts initially present in saline profile up to $70 \%$ by using an amount of water equivalent to $1 / 3$ the thickness of the soil. This improves if the immersion continues with enough drainage water (Hoffman 1980). Data have showed that with rice cultivation over years and a good drainage system, desalinization of the land can be achieved.

Leaching combined with different cropping systems, such as management practices to restore degraded soils affected by salinization processes, showed that from the soil surface to a shallow depth, soil acidity was close to neutral with a $\mathrm{pH}$ range of 6.75-7.27 (Fig.8). At a greater depth $(20-30 \mathrm{~cm})$, data showed acidic soil. At any rate, soil $\mathrm{pH}$ at both depth levels presented optimal conditions for cropping after leaching processes were conducted. 


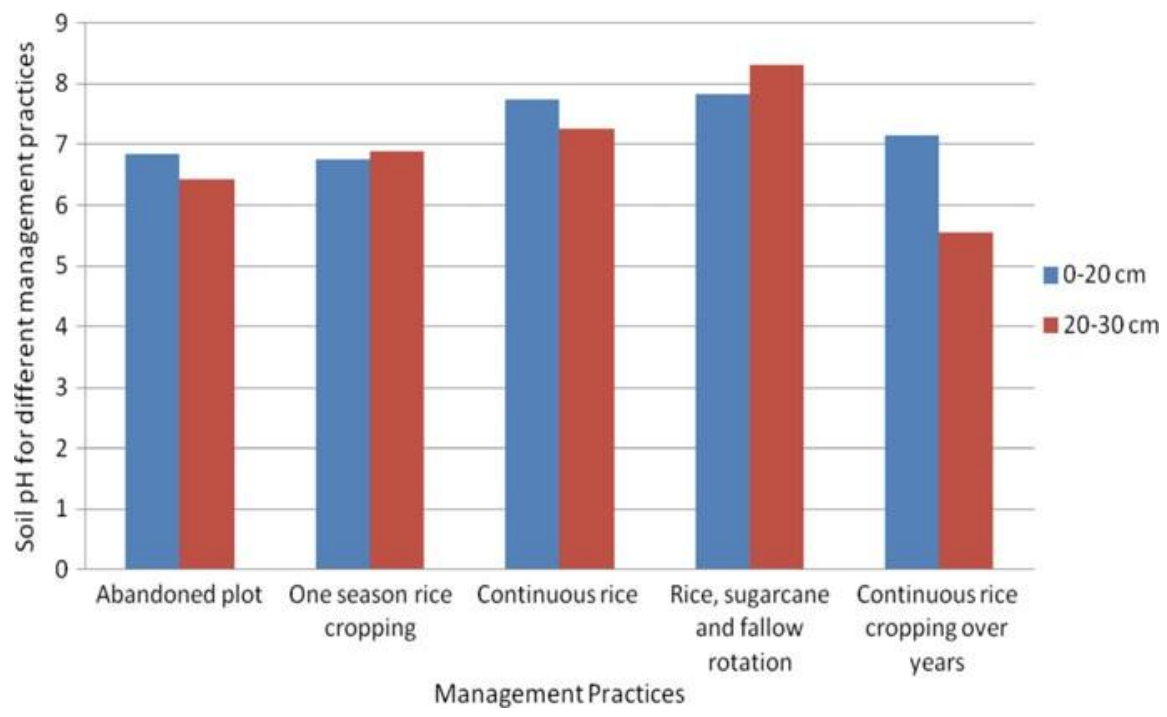

Fig. 8 Changes in soil pH between management practices

\section{Conclusion}

Desalinization techniques used for 2 years showed convincing results not only for restoring degraded soils for better cropping but also for improving the socioeconomic environment through an increase of agricultural land tenure for food security. The positive impact of leaching saline soils was noticed in the gradual increase in arable land and thus potential for crop production and improvement in soil quality. Once recovered from salinization, these lands can represent the most suitable zones for cropping compared to the uplands. Globally, desalinization through rice cultivation presents an economic and ecological cost, which should be taken into account when it comes to restoring degraded salty soils for crop production.

\section{References}

Adger WN, Agrawala S, Mirza MMQ, Conde C, O’Brien K, Pulhin J, Pulwarty R, Smit B, Takahashi K (2007) Assessment of adaptation practices, options, constraints and capacity. In: Parry ML, Canziani OF, Palutikof JP, van der Linden PJ, Hanson CE (eds) Climate change 2007: impacts, adaptation and vulnerability. Contribution of Working Group II to the Fourth Assessment Report of the Intergovernmental Panel on Climate Change. Cambridge University Press, Cambridge, pp 717-743

Boivin P, Le Brusq JY (1985) Désertification et salinisation des terres au Sénégal: problèmes et remèdes. In: Séminaire national sur la désertification. ORSTOM, Dakar 5 p. multigr. Séminaire National sur la Désertification, Saint-Louis (SEN), 22-26 April 1985 
Boivin P, Brunet D, Gascuel C, Zante P, et Ndiaye JP (1995) Les sols argileux de la région de Nianga-Podor: répartition, caractéristiques, aptitude et risques de dégradation sous irrigation. In Nianga, laboratoire de l'agriculture irriguée dans la moyenne vallée du fleuve Sénégal, ORSTOM, coll. Colloques et Séminaires, Paris, France, pp 67-81

Boivin P, Favre F, Maeght JL (1998) Les sols de la moyenne vallée du fleuve Sénégal: caractéristiques et évolution sous irrigation. Etude et Gestion des Sols 5:235-246

Breman H, Sissoko K (1994) L'intensification agricole au Sahel. Karthala, Paris, p 975

Brown ME, Funk C (2008) Food security under climate change. Science 319:580-581

Ceuppens J, Wopereis MCS (1999) Impact of non-drained irrigated rice cropping on soil salinization in the Senegal River Delta. Geoderma 92:125-140

Charollais M, Weber V (1994) Evolution des sols irrigués dans la moyenne vallée du fleuve Sénégal. Sodisation et alcalinisation. Mémoire de fin d'études EPFL, Département de Génie Rural, IATE, Option Pédologie, p. 46 et annexes

Ciss AH (2002) Contribution à l'étude du bilan hydrique de la canne à sucre dans les périmètres irrigués de la CSS, mémoire de maitrise. Université Gaston Berger, Saint-Louis

D'Aquino P (1995) Etude de la salinité à Thiagar par l'utilisation d'un conductivimètre électronique. ISRA, Saint-Louis, p 29

Deckers J, Raes D, Merckx R, Diallo AM (1994) The fate of salic and thionic fluvisols under irrigated rice in the Senegal river delta. Pedologie XLIII-3:389-401

Diop T (2013) Les techniques de désalinisation des terres de la Compagnie Sucrière Sénégalaise: impact sur l'environnement. Mémoire de Master. Ecosystèmes et Environnement. Université Gaston Berger de Saint-Louis, Saint-Louis, Sénégal, p 85

Dunia T (1995) Suivi de la salinisation dans les périmètres irrigués par télédétection et système d'information Géographique. p 136

Enda (1986) Enjeux de l'après barrage vallée du Sénégal. p 632

Farkas CS et al (2008) A chernozem soil water regime response to predicted climate change scenarios. Soil Water Res 3(Special Issue 1):558-567

Gobin A, Jones R, Kirkby M, Campling P, Govers G, Kosmas C, Gentile AR (2003) Indicators for pan-European assessment and monitoring of soil erosion by water. Environ Sci Policy $7(1): 25-38$

Guillaumie K et al (2005) La sécheresse au Sahel, un exemple de changement climatique. Atelier Changement Climatique ENPC-Département VET, p 40

Harnos ZS, Csete L (2008) Climate change: environment-risk-society. Research results. Szaktudás Kiadó Ház, Budapest, 380pp (In Hungarian)

Hoffman GJ (1980) Guidelines for reclamation of salt-affected soils. In: Proceedings of the Inter-American Salinity and Water Management conference, Juarez, Mexico, 11-12 Dec 1980, pp 49-64

Institut National de Pédologie (2008) Estimation des terres affectées par le processus de salinisation au Sénégal. Rapport annuel. p 38

Lal R (2000) Soil management in the developing countries. Soil Sci 165:57-72 [27]

Lal R, Stewart BA (1994) Soil processes and water quality. In: Lal R, Stewart BA (eds) Soil processes and water quality. Lewis Publishers, Boca Raton, 398 pp

Lal R, Hall GF, Miller FP (1989) Soil degradation: I. Basic processes. Land Degrad Rehabil 1:51-69 [13]

Le Brusq JY, et Loyer JY (1983) Evolution de la salinité des sols et des eaux en relation avec la riziculture submergée dans le delta du fleuve Sénégal (campagne 1981-1982). ORSTOM, Dakar, Sénégal, p 18

Le Gal P-Y (2001) Gestion des systèmes de culture et organisation collective de la production: élaboration d'une démarche d'aide à la gestion des périmètres irrigués. ATP 10/98, p 14

Loyer JY (1989) Degradation saline des sols induite par l'irrigation en domaine sahelien. ORSTOM, Paris, pp 531-539 
Marius C (1985) Contribution à l'étude des mangroves du Sénégal et de Gambie. Ecologiepédologie-géochimie. Mise en valeur et aménagement (Résumé de thèse), Thèse de doctorat en sciences-Ecologie de la Terre. Cahiers ORSTOM, Série Pédologie XXI, pp 12-131

Marius C (1995) Effets de la sécheresse sur l'évolution des mangroves du Sénégal et de la Gambie. Sécheresse 6:123-125

Michel P (1973) Les bassins des fleuves Sénégal et Gambie. Etude géographique. Mémoire de l'ORSTOM Paris, Tome 1. p 365

Parry M, Rosenzweig C, Livermore M (2005) Climate change, global food supply and risk of hunger. Philos Trans R Soc B 360:2125-2138. doi:10.1098/rstb.2005.1751

Poitevin F (1993) Etude d'impact des techniques culturales sur les aménagements hydro-agricoles dans la région de Podor (Sénégal), mémoire de quatrième année de l'ESAP, multigr. ORSTOM Dakar, $\mathrm{p} 53$ et annexes

Sadio S (1986) Etude pédologique des facteurs de mortalité des essences forestières introduites en milieux sales au Sénégal. In Reboisement des Niayes et du Sine-Saloum. ORSTOM, Dakar, Sénégal, p 105

Sadio $S$ (1991) Pédogènese et potentialités forestières des sols sulfatés acides salés des tannes du Sine Saloum, Sénégal. ORSTOM, Bondy, p 269

Soil Survey Staff (1992) Keys to soil taxonomy, 6th edn. United States Department of Agriculture, p 306

Sy BA (2008) Dynamique Eolienne Actuelle Dans Le Delta Du Fleuve Sénégal. In: Contribution A L'étude Géomorphologique Du Sénégal Septentrional. Thèse De $3^{\text {eme }}$ Cycle, Université Gaston Berger, Saint-Louis, Sénégal, p 251

Tubiello FN, Fischer G (2007) Technological forecasting and social change, reducing climate change impacts on agriculture: global and regional effects of mitigation, 2000-2080, 74(7):1030-1056

Tubiello FN, Fischer G (2013) Climate change impacts on global food security. Science 341 (6145):508-513

Várallyay G (1990) [Fertilizer - liquid manure - drinking water relationships] (H.e). Egeszsegtudomany XXXIV(2):126-137

Várallyay G (1994) Climate change, soil salinity and alkalinity. In: Sounsevell MDA, Loveland RJ (eds) Soil responses to climate change, vol 23, NATO ASI series. Springer, London, pp 3-11

Várallyay G (2007) Potential impacts of climate change on agro-ecosystems. Agric Conspec Sci $72(1): 1-8$

Várallyay G (2009) The impact of climate change on soils and on their water management. Abstract Volume. Symposium and 3rd training course 'Climate change: challenge for training of applied plant scientist. Impact of climate change on crop production'. 'Agrisafe' (Martonvásár, 7-11 Sept, 2009). Agricultural Research Institute of HAS, Martonvásár, pp 6-15

Várallyay G (2010) Soils as water reservoir and soil aridification. Klima 21 Fuzetek (59):3-25

Várallyay G, Farkas C (2008) Impact of climate change on soils in Hungary. In: Harnos Z, Csete L (eds) Climate change: environment-risk-society. Research results. Szaktudás Kiado Haz, Budapest, pp 91-129

Wopereis MCS, Donvan C, Nebié B, Guindo D, Ndiaye MK (1999) Soil fertility management in irrigated rice systems in the Sahel and Savanna regions and West Africa. Part 1: agronomic analysis. Field Crop Res 61(2):125-145

Zeng N (2003) Atmospheric science. Drought in the Sahel. Science 302:999-1000 